\title{
ANALISA KEBIJAKAN PEMERINTAH KOTA PANGKALPINANG 2013-2018
}

\author{
Muhammad Bayu Nanda \\ bayusanjaya366@gmail.com \\ Universitas Bangka Belitung;
}

\begin{abstract}
Abstrak
Hakikat pembangunan dapat diartikan secara umum sebagai suatu proses perubahan masyarakat dari kondisi saat ini menjadi kondisi yang dicita-citakan. Suatu perencanaan pembangunan yang terpadu, terukurserta dapat dilaksanakan dan berkelanjutan diperlukan dalam perubahan tersebut. Di era disentralisasi dan implementasi kebijakan dan otonomi daerah seperti yangterjadi saat ini berimbas terhadap kekuasaan yang lebih besar oleh pemerintah daerah untuk menyelenggarakan kewenangan pemerintah di bidang tertentu, salah satu diantaranya adalah pemerintah daerah. Pemerintah daerah memiliki keleluasaan untuk mengembangkan segenap potensi daerah dan mengelola sumber kekayaan alamnya serta menentukan prioritas dan arah pembangunan ekonomi daerah.

Perencanaan pembangunan ekonomi suatu daerah sangat memerlukan berbagai macam data sebagai dasar penentuan strategi dan arah kebijakan agar pembangunan dapat terarah dan mendapatkan hasil yang sesuai dengan target awal yang diharapkan.

Guna meningkatkan kemampuan analisis mengenai kegiatan perencanaan pembangunan daerah dan terdorong oleh keingintahuan akan karakteristik suatu wilayah,dalam tulisan ini kami akan mengulas mengenai analisis beberapa kebijakan perencanaan pembangunan ekonomi daerah dalam lingkup Kota Pangkalpinang.
\end{abstract}

Kata Kunci: Analisa, Kebijakan, Pangkalpinang

\section{PENDAHULUAN}

Hakikat pembangunan dapat diartikan secara umum sebagai suatu proses perubahan masyarakat dari kondisi saat ini menjadi kondisi yang dicita-citakan. Suatu perencanaan pembangunan yang terpadu, terukurserta dapat dilaksanakan dan berkelanjutan diperlukan dalam perubahan tersebut. Undang-Undang Nomor 25 Tahun 2004 tentang "Sistem Perencanaan Pembangunan Nasional dalam Pasal 1 menyatakan, Sistem Perencanaan Pembangunan Nasional adalah satu kesatuan tata cara perencanaan pembangunan untuk menghasilkan rencana-rencana pembangunan dalam jangka panjang, menengah dan tahunan yang dilaksanakan oleh unsur penyelenggara negara dan masyarakat di tingkat pusat dan daerah dan UndangUndang Nomor23 Tahun 2014 tentang Pemerintahan Daerah mengamanatkan bahwa Pemerintahan Daerah Propinsi, Kabupaten/Kota dalam rangka menyelenggarakan pemerintahannya harus menyusun perencanaan pembangunan.

Di era disentralisasi dan implementasi kebijakan dan otonomi daerah seperti yangterjadi saat ini berimbas terhadap kekuasaan yang lebih besar oleh pemerintah daerah untuk menyelenggarakan kewenangan pemerintah di bidang tertentu, salah satu diantaranya adalah pemerintah daerah. Pemerintah daerah memiliki keleluasaan untuk mengembangkan segenap potensi daerah dan mengelola sumber kekayaan alamnya serta menentukan prioritas dan arah pembangunan ekonomi daerah.

Perencanaan pembangunan ekonomi suatu daerah sangat memerlukan berbagai macam data sebagai dasar penentuan strategi dan arah kebijakan agar pembangunan dapat terarah dan mendapatkan hasil yang sesuai dengan target awal yang diharapkan. Konsep tentang perencanaan pembangunan ekonomi tidak pernah lepas pembangunan ekonomi. Pembangunan ekonomi merupakan suatu proses yang diharapkan dari proses perencanaan yang telah dijalankan, sedangkan pembangunan ekonomi daerah merupakan bagian dari pembangunan ekonomi nasional. Pada hakikatnya antara pembangunan ekonomi nasional dan pembangunan ekonomi daerah tidak ada yang berbeda baik dalam lingkup 
definitif maupun secara terminologis, yang membedakan hanyalah cakupan atau lingkup pembangunan tersebut. Pembangunan nasional biasanya dalam cakupan negara, sedangkan pembangunan daerah berada dalam cakupan provinsi ataupun kabupaten/kota. Semua kegiatan perencanaan pembangunan ekonomi daerah pada dasarnya akan difokuskan untuk menjaga keluaran dari semua kegiatan pembangunan mengarah pada pencapaian tujuan pembangunan baik yang bersifat jangka pendek maupun jangka panjang.

Guna meningkatkan kemampuan analisis mengenai kegiatan perencanaan pembangunan daerah dan terdorong oleh keingintahuan akan karakteristik suatu wilayah,dalam tulisan ini kami akan mengulas mengenai analisis beberapa kebijakan perencanaan pembangunan ekonomi daerah dalam lingkup Kota Pangkalpinang. Kota Pangkalpinang sebagai salah satu Ibu kotanya Bangka-Belitung yang ada di Provinsi Kep. Bangka-Belitung merupakan salah satu kota yang cukup berkembang pesat dalam hal pembangunan ekonominya dibandingkan dengan kabupaten lainnya yang ada di Bangka Belitung. Oleh karena itu Kota Pangkalpinang terpilih sebagai daerah yang akan dianalisis dalam proposal ini.

Perencanaan pembangunan ekonomi pada suatu daerah, khususnya di Kota Pangkalpinang sangat memerlukan berbagai macam data sebagai dasar penentuan strategi dan arah kebijakan agar pembangunan dapat terarah dan mendapatkan hasil yang sesuai dengan target awal yang diharapkan. Oleh karena itu, proposal ini menganalisis kebijakan pembangunan daerah yang ada di Kota Pangkalpinang? Adapun tujuan dari ini adalah untuk merangkum kebijakan pembangunan daerah yang ada di Kota Pangkalpinang.

\section{TINJAUAN PUSTAKA}

\subsection{Konsep Pembangunan Ekonomi}

Menurut W. Arthtur Lewis menjabarkan konsep pemabangunan sebagai

1. Perencanaan seringkali dikaitkan dengan faktor letak geografis, bangunan tempat tinggal dan lainnya.

2. Perencanaan mempunyai arti keputusan atas penggunaan dana pemerintah pada masa mendatang.

3. Suatu perekonomian yang terencana adalah suatu perekonomian setiap unit produksi hanya memanfaatkan sumberdaya manusia, bahan baku, dan peralatan yang dialokasikan dengan jumlah tertentu dan menjual produknya hanya kepada perusahaan atau perorangan yang ditunjuk oleh pemerintah.

4. Perencanaan terkadang juga bermakna setiap upaya penentuan sasaran produksi yang dilakukan oleh pemerintah

5. Penetapan sasaran (goals) untuk perekonomian secara keseluruhan

6. Perencanaan terkadang dipakai untuk menggambarkan sebuah sarana

Secara umum pembangunan ekonomi merupakan suatu proses yang menyebabkan yang menyebabkan pendapatan per kapita penduduk suatu masyarakat meningkat dalam jangka yang panjang, disertai dengan perubahan ciri-ciri penting suatu masyarakat, yaitu perubahan dalam hal teknologi, pola pikir masyarakat maupun kelembagaaan. Berdasarkan kesimpulan diatas pembangunan ekonomi memiliki 4 sifat penting, yaitu:

1. Suatu proses

pembangunan ekonomi merupakan suatu proses, artinya pembangunan ekonomi itu berlangsung berlangsung secara terus-menerus bukan merupakan kegiatan yang sifatnya insidental (tidak sengaja).

2. Usaha untuk meningkatkan pendapatan perkapita

Pembangunan ekonomi terjadi apabila adanya kenaikan dalam hal pendapatan perkapita, karena kenaikan pendapatan kenaikan per kapita itu merupakancerminan terjadinya kesejahteraan ekonomi masyarakat.

3. Kenaikan pendapatan per kapita berlangsung dalam jangka Panjang 
Pendapatan per kapita secara rata-rata meningkat dari tahun ke tahun. Namun, hal tersebut bukan berarti bahwa pendaptan per kapita harus mengalami kenaikan secara terusmenerus, tetapi pada suatu waktu tertentu dapat turun, namun turunnya tidak terlalu besar.

4. Kenaikan pendapatan per kapita diikuti dengan terjadinya perubahan teknologi atau kelembagaan.

Maksudnya, dikatakan terjadi pembangunan ekonomi bukan saja berarti peningkatan pendapatan per kapita, namun kenaikan pendapatan per kapita juga harus diikuti dengan terjadinya perubahan teknologi. Misalnya di sektor pertanian, yang dulunya pengolahan lahan dengan menggunakan tenaga hewan, sekarang berganti meggunkana traktor.

\subsection{Perencanaan Pembangunan}

Perencanaan adalah suatu himpunan dari keputusan akhir, keputusan awal dan proyeksi ke depan yang konsisten dan mencakup beberapa periode waktu, dan tujuan utamanyaadalah untuk mempengaruhi seluruh perekonomian di suatu negara(Brobowski1964). Disisi lain Campbell \& Fainstain (1999), dalam pembangunan Kota atau daerah dipengaruhi sistem ekonomi kapitalis atau demokratis. Dalam konteks tersebut maka pada prakteknya perencanaan tidak dapat dipisahkan dengan suasana politik kota atau daerah sebab keputusan-keputusan publik mempengaruhi kepentingankepentingan lokal. Hal ini menjadi relevan apabila kekuasaan mempengaruhi perencanaan. Ketika perencanaan telah dipengaruhi oleh sistem politik suatu kota atau daerah sebagaiman pernyataan di atas, maka sebenarnya yang terjadi adalah wilayah rasional yang menjadi dasar dalam perencanaan telah kehilangan independensinya.

Menurut Sjafrizal (2009), dalam konteks perencanaan pembangunan secara umum adalah cara atau teknik untuk mencapai tujuan pembangunan secara tepat, terarah, dan efisien sesuai dengan kondisi negara atau daerah bersangkutan. Oleh karena itu, perencanaan pembangunan hendaklah bersifat implementif (dapat dilaksanakan) dan aplikatif (dapat diterapkan).

Menurut ML Jhingan (1984, diacu dalam Sjafrizal 2009), seorang ahli perencanaan pembangunan bangsa India memberikan definisi yang lebih kongkrit mengenai Perencanaan Pembanguna tersebut, yaitu ; "Perencanaan Pembangunan pada dasarnya adalah merupakan pengendalian dan pengaturan perekonomian dengan sengaja oleh suatu penguasa (pemerintah) pusat untuk mencapai suatu sasaran dan tujuan tertentu di dalam jangka waktu tertentu pula.

Kegiatan perencanaan pembangunan pada dasarnya merupakan kegiatan riset/ penelitian, karena proses pelaksanaannya akan banyak menggunakan metode-metode riset, mulai dari teknik pengumpulan data, analisis data, hingga studi lapangan/kelayakan dalam rangka mendapatkan data-data yang akurat, baik yang dilakukan secara konseptual/dokumentasi maupun eksperimental.

Perencanaan pembangunan tidak mungkin hanya dilakukan diatas meja, tanpa melihat realita dilapangan. Data-data real lapangan sebagai data primer merupakan ornamen-ornamen penting yang harus ada dan digunakan menjadi bahan dalam kegiatan perencanaan pembangunan.

Dengan demikian perencanaan pembangunan dapat diartikan sebagai suatu proses perumusa alternatif-alternatif atau keputusan-keputusan yang didasarkan pada data-data dan fakta-fakta yang akan digunakan sebagai bahan untuk melaksanakan suatu rangkaian kegiatan/aktivitas kemasyarakatan, baik yang bersifat fisik (material) maupun non fisik (mental dan spiritual), dalam rangka mencapai tujuan yang lebih baik.

Selanjutnya perencanaan akan menjadi tidak efektif dan efesien, bersifat mendua antara idealisme "kepakaran seorang perencana" atau mengikuti selera atau kemauan-kemauan, sehingga berimplikasi pada kualitas perencanaan dalam pencapaian goal (tujuan) dan objektif (sasaran) yang dituju. Di samping itu, perencanaan merupakan pekerjaan yang menyangkut wilayah publik maka komitmen seluruh pemangku kepentingan (stake holder) yang terlibat sangat dibutuhkan sehingga hasil perencanaan dapat dibuktikan dan dirasakan manfaatnya. 


\subsection{Perencanaan Pembangunan Daerah}

Dalam hubungannya dengan suatu daerah sebagai area (wilayah) pembangunan dimana terbentuk konsep perencanaan pembagunan daerah (Riyadi et al. 2004), perencanaan pembangunan daerah adalah suatu proses perencanaan yang dimaksudkan untuk melakukan perubahan menuju arah yang lebih baik bagi suatu komunitas masyarakat, pemerintah dan lingkungannya dalam wilayah/daerah tertentu dengan memanfaatkan atau mendayagunakan berbagai sumber daya yang ada dan harus memilki orientasi yang bersifat menyeluruh, lengkap, tetapi tetap berpegang pada azas prioritas.

Perencanaan Pembangunan Daerah (PPD) akan membentuk tiga hal pokok yang meliputi, perencanaan komunitas, menyangkut suatu area (daerah), dan sumber daya yang ada di dalamya. Pentingnya orientasi holisti dalam perencanaan pembangunan daerah, karena dengan tingkat kompleksitas yang besar tidak mungkin kita mengabaikan masalah-masalah yang muncul sebagai tuntutan kebutuhan sosial yang tak terelakkan. Tetapi dipihak lain adanya keterbatasan sumberdaya yang dimiliki tidak memungkinkan pula untuk melakukan proses pembangunan yang langsung menyentuh atau mengatasi seluruh permasalahan dan tuntutan secara sekaligus. Dalam hal inilah penentuan prioritas perlu dilakukan, yang dalam prakteknya dilakukan melalui proses perencanaan.

Melakukan perencanaan pembangunan daerah berbeda dengan melakukan perencanaan proyek atau perencanaan-perencanaan kegiatan yang bersifat lebih spesifik dan mikro. Proses perencanaan pembangunan daerah jauh lebih kompleks dan rumit, karena menyangkut perencanaan pembangunan bagi suatu wilayah dengan berbagai komunitas, lingkungan dan kondisi sosial yang ada didalamnya. Apalagi bila mencakup wilayah pembangunan yang luas, kultur sosialnya amat heterogen, dengan tingkat kepentingan yang berbeda. Berdasarkan uraian-uraian diatas, dapat diartikan bahwa; perencanaan pembangunan daerah adalah suatu proses penyusunan tahapan-tahapan kegiatan yang melibatkan berbagai unsur didalamnya, guna pemanfaatan dan pengalokasian sumber-sumber daya yang ada dalam rangka meningkatkan kesejahteraan sosial dalam suatu lingkungan wilayah/daerah dalam jangka waktu tertetu.

Menurut Affandi Anwar \&Setia Hadi dalam Riyadi (2004), perencanaan pembangunan wilayah diartikan sebagai suatu proses atau tahapan pengarahan kegiatan pembangunan disuatu wilayah tertentu yang melibatkan interaksi antara sumberdaya manusia dengan sumberdaya lain, termasuk sumberdaya alam dan lingkungan melalui investasi.

Dikatakan wilayah tertentu karena memang implementasinya hanya dapat digunakan didaerah tertentu, dimana penelusuran lapangan dilakukan, sehingga tidak mungkin diimplementasikan didaerah lain secara utuh, kecuali untuk hal-hal tertentu saja yang memiliki kesamaan kondisi dan tuntutan kebutuhan yang hampir sama.Jenssen (1995, diacu dalam Riyadi, Deddy Supriady Baratakusumah 2004), perencanaan pembangunan daerah harus memperhatikan hal-hal yang bersifat kompleks tadi, sehingga prosesnya harus memperhitungkan kemampuan sumberdaya yang ada, baik sumberdaya manusia, sumber daya fisik, sumber daya alam, keuangan, serta sumber-sumber daya lainnya.

Dalam konteks ini, disebut dengan istilah pembangunan endogen, atau dengan kata lain pembangunan yang berbasis potensi.Selain itu, perencanaan yang mempertimbangkan kondisi spatial suatu daerah juga menjadi hal penting dalam proses perencanaan pembangunan daerah. Pembangunan daerah akan mencakup suatu raung tertentu, sehingga diperlukan adanya penataan ruang yang efektif, dimana tataruang akan mempengaruhi proses pembangunan beserta implikasinya.

Ciri-ciri pembangunan daerah menurut Riyadi et al. (2004) meliputi hal-hal sebagai berikut:

1. Menghasilkan program-program yang bersifat umum.

2. Analisis perencanaan bersifat makro/luas.

3. Lebih efektif dan efisien digunakan untukperencanaan jangka menengah dan panjang.

4. Memerlukan pengetahuan secara interdisipliner,general dan universal, namun tetap memiliki spesifikasi masing-masing yang jelas.

5. Fleksibel dan mudah untuk dijadikan sebagaiacuan perencanaan pembangunan jangka pendek (1 tahunan).

Dengan melihat berbagai pengertian mengenai perencanaan maupun perencanaan pembangunan di atas dapat disimpulkan bahwa tidak semua perencanaan adalah merupakan perencanaan pembangunan. Suatu perencanaan disebut sebagai perencanaan pembangunan apabila dipenuhi berbagai ciri-ciri tertentu serta adanya tujuan yang bersifat pembangunan. Ciri suatu perencanaan pembangunan (agent 
of development) oleh karena perencanaan pembangunan sendiri merupakan bagian dari administrasi pembangunan yang menjadi bagian kewenangan pemerintah.

Perencanaan Pembangunan Daerah memerlukan Koordinasi dari semua unsur yang terlibat dalam rangka menghasilkan sebuah program dan kegiatan yang holistik dan komprehensif. Selain itu Perencanaan Pembangunan Daerah harus mampu menentukan prioritas program dan kegiatan berdasarkan fakta dan data dari potensi daerahnya, serta harus mempunyai sumberdaya yang mempunyai kemampuan yang baik secara interdisipliner, sehingga koordinasi sekali lagi sangat diperlukan dalam pembuatan sebuah perencanaan pembangunan yang terintegrasi, tersinkronisasi, dan menyeluruh.

\section{METODE \\ 3.1 Ruang Lingkup Penelitian}

Untuk memperjelas yang akan dibahas dan agar tidak terjadi pembahasan yang meluas atau menyimpang, maka perlu kiranya dibuat batasan penelitian. Adapun ruang lingkup pembangunan yang akan dibahas dalam penulisan ini, sebagai berikut:

1) Pendidikan

2) Kesehatan

3) Koperasi dan Usaha Kecil Menengah

4) Penanaman Modal

5) Pertanian

6) Energi Dan Sumber Daya Mineral

7) Pariwisata

8) Kelautan dan perikanan

9) Perdagangan

10) Industri

\section{Waktu Penelitian}

Waktu yang digunakan peneliti untuk penelitian ini dilaksanakan dari 1 Juli -16 Agustus 2018 dengan mengambil data di Rencana Pembangunan Jangka Menengah Daerah (RPJMD) 2017-2022 dan Rencana Kinerja Pembangunan Daerah (RKPD). Adapun data yang digunakan adalah data tentang kebijakan perencanaan pembangunan daerah Kota Pangkalpinang. Tempat pelaksanaan penelitian ini adalah di Badan PerencanaanPembangunan Daerah (BAPPEDA) Kota Pangkalpinang.

Data yang digunakan dalam penelitian adalah data sekunder diperoleh dari sumber penelitian atau lokasi penelitian berhubungan dengan permasalahan yang diteliti. Data sekunder penelitian ini diperoleh dengan observasi lapangan dan mengambil data dari sumber terkait yaitu RPJMD dan RKPD. Metode yang digunakan untuk penelitian ini adalah metode Kualitatif dengan pendekatan deskriptif yang bertujuan untuk menggambarkan serta memahami dan menjelaaskan bagaimana proses perumusan kebijakan teknis dalam perencanaan pembangunan daerah Kota Pangkalpinang Penelitian kualitatif adalah Penelitian yang memecahkan masalahnya dengan data empiris (Masyuri dan Zainudin 2008:12).

\section{HASIL}

\subsection{Profil Singkat Kota Pangkalpinang}

Kota Pangkalpinang adalah salah satu kota di Indonesia yang merupakan bagian dari ProvinsiKepulauan Bangka Belitung. Secara astronomis, Kota Pangkal Pinang terletak antara 20,4'-20,10' LS dan 106,04'-106,07' BT. Kota ini terletak di bagian timur Pulau Bangka. Kota Pangkalpinang terbagi dalam 7 kecamatan dan memiliki 42 kelurahan. (BPS.2013).

Kota Pangkalpinang memiliki wilayah seluas $118,41 \mathrm{~km}^{2}$ dan jumlah penduduk berdasarkan Sensus Penduduk 2010 sebanyak 328,167 jiwa dengan kepadatan 1.955 jiwa $/ \mathrm{km}^{2}$. Saat ini dipimpin oleh Wali Kota Muhammad Irwansyah, yang sebelumnya dipimpin oleh Zulkarnain Karim yang menjabat untuk dua periode (2003-2013). Sungai Rangkui membelah kota yang memiliki julukan "BERARTI" (Bersih, Aman, Rapi, Tertib, Indah). Kota ini berpusat di Jalan Merdeka sebagai titik nol kilometer kota. 
Populasi Kota Pangkalpinang kebanyakan dibentuk oleh etnis Melayu dan Tionghoa suku Hakka yang datang dari Guangzhou. Ditambah dengan suku pendatang seperti Batak, Minangkabau, Palembang, Sunda, Jawa, Madura, Banjar, Bugis, Manado, Flores dan Ambon. Kota Pangkal Pinang merupakan pusat pemerintahan, pusat pemerintahan kota di Kelurahan Bukit Intan, dan pusat pemerintahan provinsi dan instansi vertikal di Kelurahan Air Itam. Kantor pusat PT. Timah Tbk. juga berada di sini. Pangkal Pinang juga merupakan pusat aktivitas bisnis/perdagangan dan industri di Bangka Belitung.

\subsection{Identifikasi Kebijakan Pembangunan Daerah}

Dalam penyusunan rencana strategis pembangunan daerah setiap perencanaan pembangunan disusun berdasarakan tolak ukur dan kriteria tertentu yang menjadikan kebijakan tersebut cukup urgent untuk segera dilaksanakan dan diharapkan dari implementasi kebijakan tersebut akan memberikan dampak yang besar terhadap perekonomian daerah. Seperti telah disebutkan pada pembahasan analisis wilayah kali ini kami menjadikan Kota Pangkalpinang sebagai daerah analisis. Prioritaspembangunanjangkapanjang Kota Pangkalpinang difokuskanpadaupayauntukmenjagadanmeningkatkanperekonomiandaerahsertaupayapemenuha nkapasitasdankualitas SDM, keterkaitan industri ke depan dan ke belakang dapat menjadi perhatian dan tumpuan utama. Sementara itu, perhatian terhadap pengembangan kualitas SDM dan dalam semua aspek menjadi perhatian sejalan dengan upaya untuk semakin memantapkan pembangunan ekonomi daerah. Dukungan SDM yang berkualitas, profesional, berwawasan IPTEK dan berbekal IMTAK yang kuat menjadi satu kesatuan dengan upaya untuk mempersiapkan Kota Pangkalpinang dalam menghadapi tantangan global. Peningkatan kualitas SDM ini menjadi sangat penting untuk diprioritaskan dalam upaya untuk menjadikan masyarakat Pangkalpiang sebagai subjek dan bukan objek dari pesatnya pelaksanaan pembangunan di Kota Pangkalpinang. Pada periode ini, diyakini perkembangan teknologi (terutama teknologi informasi) dan ilmu pengetahuan sudah sangat maju dan karenanya pengembangan SDM di sini adalah SDM yang mampu mengambil manfaat dari kemajuan teknologi dan ilmu pengetahuan yang sesuai dengan potensi ekonomi yang dimiliki.

Berdasarkan data BPS (2013) perekonomian Kota Pangkalpinang diharapkan dapat terus meningkat.Pertumbuhan PDRB sebagai salah satu indikator dari kondisi perekonomian daerah Kota Pangkalpinang ditargetkan dapat tumbuh sebesar5,25sementara itu Indeks Pembangunan Manusia (IPM) yang mengindikasikan tingkat kualitas SDM diharapkan meningkat dari 76.14 ditahun 2017 meningkat hingga 76.86 di tahun 2017.

Guna mencapai target sasaran pokok pembangunan daerah tersebut, maka:

\subsubsection{Pada sasaran pokok meningkatnya perekonomian daerah, arah kebijakan prioritas} yang dilaksanakan adalah:

1) Peningkatan kualitas dan produktifitas Pendidikan

2) Penempatan tenaga kerja dan penciptaan lapangan pekerjaan bagi pencari kerja pada semua sektor pembangunan;

3) Mendorong pengembangan standarisasi SDM, produk dan jasa KUKM untuk meningkatkan daya saing;

4) Peningkatkan dan pengembangan Sumber Daya Manusia dan industri pengolahan Sumber Daya Alam;

5) Pemenuhan energi listrik dan peningkatan rasio elektrifikasi;

6) Peningkatan tata kelola dan nilai tambah produk sumber daya mineral;

7) Pengembangan produk unggulan daerah, serta mendorong terwujudnya koordinasi, sinkronisasi, keterpaduan dan kerjasama antarsektor, antar pemerintah, dunia usaha, dan masyarakat dalam mendukung peluang berusaha dan investasi di daerah;

8) Pemantapan ketahanan pangan yang menjamin ketersediaan, distribusi, keterjangkauan, keamanan dan mutu pangan;

9) Peningkatan kuantitas dan kualitas SDM, ekonomi kreatif, kebudayaan, peran serta masyarakat dan kelembagaan pariwisata;

10) Peningkatan sarana dan prasarana pengembangan aparatur Negara;

11) Penyusunan kebijakan dan implementasi perlindungan lahan pertanian berkelanjutan; 
12) Peningkatan potensi ekonomi lokal berbasis agri-bahari yang berwawasan lingkungan dan berdaya saing global;

\subsubsection{Pada sasaran pokok terpenuhinya kapasitas dan kualitas SDM, arah kebijakan yang} dilaksanakan adalah:

1) Peningkatan akses pelayanan pedidikan, peningkatan mutu pendidikan serta peningkatan relevansi dan daya saing;

2) Peningkatan kesadaran masyarakat dalam berperilaku hidup bersih dan sehat;

3) Peningkatan pelayanan kesehatan dasar dan kesehatan rujukan;

4) Pemenuhan kuantitas dan kualitas tenaga kesehatan.

\subsection{Strategi dan Arah Kebijakan}

Strategi dan arah kebijakan merupakan rumusan perencanaan komprehensifbagaimana pemerintah daerah mencapai tujuan dan sasaran rancangan pembangunan sesuai periode dengan efektif dan efisien. Dengan pendekatan yang komprehensif, strategi juga dapat digunakan sebagai sarana untuk melakukan transformasi, reformasi, dan perbaikan kinerja birokrasi. Perencanaan strategi tidak saja mengagendakan aktivitas pembangunan, tetapi juga segala program yang mendukung dan menciptakan layanan masyarakat tersebut dapat dilakukan dengan baik, termasuk di dalamnya upaya memperbaiki kinerja dan kapasitas birokrasi, sistem manajemen, dan pemanfaatan teknologi informasi. Sedangka strategi adalah langkah-langkah atau cara dalam rangka mencapai visi dan misi pembangunan yang dijabarkan dalam tujuan dan sasaran pembangunan.

Strategi pembangunan harus didahului oleh analisis yang cermat atas keadaan yang ada di daerah. Oleh karena itu, sebelum masuk pada strategi pembangunan, diidentifikasi kekuatan, kelemahan, peluang, dan ancaman yang dimiliki oleh Kota Pangkalpinang. Kemudianditetapakan Strategi dan Arah Kebijakan untuk mencapai setiap sasaran pembangunan lengkap dengan indikator kinerja sasaran sebagai alat ukur keberhasilan pencapain sasaran pembangunan daerah yang merupakan penjabaran dari visi misi RPJMD 2013-2018Kota Pangkalpinang. Strategi dan arah kebijakan yang digunakan dalam mencapai sasaran pembangunaan.

\subsection{Rencana Program Pemerintahan dan pencapaian kinerja}

\section{Bidang Urusan Pemerintahan dan Program Prioritas Pembangunan}

\subsubsection{Pendidikan}

Tabel 4.1 Program Pendidikan

\begin{tabular}{|c|c|c|c|c|c|c|c|}
\hline \multirow{2}{*}{$\begin{array}{l}\text { PROGRAM } \\
\text { PENDIDIKAN }\end{array}$} & \multirow{2}{*}{ KINERJA AWAL RPJMD } & \multicolumn{5}{|c|}{ CAPAIAN KINERJA PROGRAM DAN KERANGKA PENDANAAN } & \multirow{2}{*}{$\begin{array}{l}\text { KINERJAAKHIR } \\
\text { PERIODE }\end{array}$} \\
\hline & & 2014 & 2015 & 2016 & 2017 & 2018 & \\
\hline PENDANAAN (TOTAL) & & $\operatorname{Rp} 52,373,235$ & Rppo,921,292 & Rp85,273,421 & Rp93,800,763 & Rp103,245,840 & Rp415,614,551 \\
\hline $\begin{array}{c}\text { Program Pendidikan } \\
\text { Usia Dini }\end{array}$ & $7.42 \%$ & $8.00 \%$ & $9.50 \%$ & $10.00 \%$ & $10.50 \%$ & $11.00 \%$ & $11.00 \%$ \\
\hline $\begin{array}{l}\text { Program Wajib } \\
\text { Belajar } 9 \text { tahun }\end{array}$ & $99.23 \%$ & $98.75 \%$ & $98.77 \%$ & $98.80 \%$ & $98.90 \%$ & $98.99 \%$ & $98.99 \%$ \\
\hline Pendidikan menengah & $97.46 \%$ & $99.05 \%$ & $99.06 \%$ & $99.07 \%$ & $99.08 \%$ & $99.09 \%$ & $99.09 \%$ \\
\hline $\begin{array}{l}\text { Program Pendidikan } \\
\text { Non Formal (AMH) }\end{array}$ & $99.21 \%$ & $100 \%$ & $100 \%$ & $100 \%$ & $100 \%$ & $100 \%$ & $100 \%$ \\
\hline $\begin{array}{c}\text { Program Mutu Tenaga } \\
\text { Pendidik }\end{array}$ & $67.29 \%$ & $70.00 \%$ & $80.00 \%$ & $90.00 \%$ & $100 \%$ & $100 \%$ & $100 \%$ \\
\hline
\end{tabular}




\section{Sumber: Data diolah}

Beberapa data pencapaian kinerja pemerintahan dari tahun 2013-2018, program dijalankan dari RPJMD dari pendidikan anak usia dini dan meningkatan rata-rata mutu pendidikan di kota pangkalpinang berhasil dengan angka melek huruf (AHM) 99,21\% diawal kinerja terus meningkat positif hingga akhir periode 100\%, meskipun diawal kinerja yang tertera di RPMJD (2013) sebesar $67.29 \%$ pemerintah mampu menjalankan program meningkatkan mutu tenaga kependidikan. Dan total pengeluaran pemerintah untuk semua program pendidikan dari 2014 mencapai Rp. 415.614.551,-Sebagai saran pemerintah tetap melakukan peningkatan untuk periode kedepannya agar mutu pendidikan di Kota Pangkalpinang mampu bersaing dengan daerah lainnya dengan acuan yang tertera pada Rancangan Kinerja Pembangunan Daerah (RKPD).

\subsubsection{Kesehatan}

\section{Tabel 4.2 Program Kesehatan}

\begin{tabular}{|c|c|c|r|r|r|r|r|}
\hline \multirow{2}{*}{ PROGRAM KESEHATAN } & \multirow{2}{*}{ KINERJA AWAL RPJMD } & \multicolumn{5}{|c|}{ CAPAIAN KINERJA PROGRAM DAN KERANGKA PENDANAAN } & KINERJA AKHIR \\
\cline { 3 - 8 } & 2014 & 2015 & 2016 & 2017 & 2018 & PERIODE \\
\hline PENDANAAN (TOTAL) & & Rp40.629.140 & Rp54.569.323 & Rp56.405.595 & Rp59.516.637 & Rp64.955.425 & Rp276.076.121 \\
\hline $\begin{array}{c}\text { Program Peningkatan } \\
\text { sarana prasarana }\end{array}$ & $60 \%$ & $65 \%$ & $70 \%$ & $75 \%$ & $80 \%$ & $85 \%$ & $85 \%$ \\
\hline $\begin{array}{c}\text { Pengembangan rumah } \\
\text { sehat }\end{array}$ & $81.80 \%$ & $82 \%$ & $83 \%$ & $85 \%$ & $90 \%$ & $95 \%$ & $95 \%$ \\
\hline $\begin{array}{c}\text { Pelayanan Kesehatan } \\
\text { Anak Balita }\end{array}$ & $82.30 \%$ & $85 \%$ & $90 \%$ & $90 \%$ & $90 \%$ & $90 \%$ & $90 \%$ \\
\hline $\begin{array}{c}\text { Program peningkatan } \\
\text { kesehatan ibu } \\
\text { melahirkan }\end{array}$ & $100 \%$ & $100 \%$ & $100 \%$ & $100 \%$ & $100 \%$ & $100 \%$ & $100 \%$ \\
\hline $\begin{array}{c}\text { Program peningkatan } \\
\text { pelayanan rumah } \\
\text { sakit }\end{array}$ & $85 \%$ & $85 \%$ & $85 \%$ & $85 \%$ & $85 \%$ & $85 \%$ & $85 \%$ \\
\hline
\end{tabular}

Sumber: data diolah

Berdasarkan tabel indikator, program yang dilakukan pemerintah Kota Pangkalpinang mengutamakan peningkatan sarana prasarana diketahui dari persentasi kinerja awal RPJMD 60\% meningkat dari tahun ketahun sebesar $0.5 \%$ hingga akhir periode $85 \%$ serta peningkatan pelayanan rumah sakit relatif sama $85 \%$. Untuk pengembangan rumah sehat dari awal tahun telah mencapai $81.80 \%$ meningkat hingga $90 \%$ diakhir tahun kinerja pemerintah 2018, dan pelayanan kesehatan Balita sebesar $82.30 \%$ terus meningkat $90 \%$ akhir periode. Dan serta peningkatan kesehatan ibu dalam cangkupan program Keluaga Berencana (KB) bisa dikatakan berhasil 100\% dari awal sampai akhir kinerja.

Alokasi total dana pengeluaran pemerintah dibidang kesehatan diakhir kinerja tahun 2018 sebesar Rp. 276.076.121,-. Sebagai saran pemerintah tetap melakukan peningkatan untuk peningkatan pelayanan rumah sakit serta sarana prasarana periode kedepannya di Kota Pangkalpinang dengan acuan yang tertera pada Rancangan Kinerja Pembangunan Daerah (RKPD). 


\subsubsection{Koperasi dan Usaha Kecil Menengah Tabel 4.3 Program Koperasi dan UMKM}

\begin{tabular}{|c|c|c|c|c|c|c|c|}
\hline \multirow{2}{*}{$\begin{array}{c}\text { PROGRAM Koperasi \& } \\
\text { UMKM }\end{array}$} & \multirow{2}{*}{ KINERU AWAL RPJMD } & \multicolumn{5}{|c|}{ CAPAIAN KINERIA PROGRAM DAN KERANGKA PENDANAAN } & \multirow{2}{*}{$\begin{array}{c}\text { KINERUA AKHIR } \\
\text { PERIODE }\end{array}$} \\
\hline & & 2014 & 2015 & 2016 & 2017 & 2018 & \\
\hline PENDANAAN (TOTAL) & & $\mathrm{Rp} 3.452 .281$ & Rp1.046.050 & Rp2.210.500 & Rp2.316.500 & Rp2.333.055 & Rp11.358.386 \\
\hline $\begin{array}{c}\text { Program usaha } \\
\text { UMKM yangkodusif }\end{array}$ & $20 \%$ & $20 \%$ & $40 \%$ & $60 \%$ & $75 \%$ & $\mathbf{8 0 \%}$ & $95 \%$ \\
\hline $\begin{array}{l}\text { Peningkatan } \\
\text { Kelentragaan } \\
\text { Koperasi aktif }\end{array}$ & $\begin{array}{l}\text { Unit Aktif:147 (72\%) } \\
\text { idak aktif: } 57(28 \%)\end{array}$ & $25 \%$ & $35 \%$ & $45 \%$ & $60 \%$ & $95 \%$ & $95 \%$ \\
\hline $\begin{array}{c}\text { Program } \\
\text { pengembangan peran } \\
\text { UMKM dalam PDRB \& } \\
\text { penyerapan teraga } \\
\text { keja }\end{array}$ & $\begin{array}{c}\text { Pemasaran antar } \\
\text { Pulau = } 10 \text { UMKM, } \\
\text { Vol. Usaha } \\
\text { UMKM=Rp_. }\end{array}$ & $25 \%$ & $35 \%$ & $45 \%$ & $60 \%$ & $95 \%$ & 95\% \\
\hline $\begin{array}{c}\text { Program } \\
\text { pengentbangan } \\
\text { peningkatan volume } \\
\text { usaha UMKM \& } \\
\text { pendukung usaha } \\
\text { bagi UKM }\end{array}$ & $\begin{array}{c}\text { 25\% Jurmah serapan } \\
\text { KUMKM terhadap } \\
\text { skimkredit mikro } \\
\text { (CSR \&KUR) }\end{array}$ & $25 \%$ & $35 \%$ & $45 \%$ & $60 \%$ & $95 \%$ & $95 \%$ \\
\hline
\end{tabular}

Sumber: data diolah

Program penciptaan iklim usaha UMKM dan Koperasi yang kondusif serta peningkatan kelembagaan koperasi aktif dengan persentase $72 \%$, peningkatan kualitas kewirausahaan yang sudah berjalan dari 10 UMKM yang melakukan pemasaran antar pulau dengan target pemerintah dalam meningkatkan PDRB serta membuka lapangan pekerjaan. Dan pemerintah mengembangkan pendukung usaha bagi UKM yang meliputi skim kredit mikro (CSR \& KUR) di mulai awal kinerja RPJMD sebesar $25 \%$ meningkat hingga 95\% diakhir periode 2018. Dari beberapa program yang dilakukan pemerintah dana yang dikeluarkan di program khususnnya Koperasi \&UMKM dengan total Rp. 11.358.386.

\subsubsection{Penanaman Modal}

\section{Tabel 4.4 Program Penanaman Modal}

\begin{tabular}{|c|c|c|c|c|c|c|c|}
\hline \multirow{2}{*}{$\begin{array}{c}\text { PROGRAM } \\
\text { Penanaman Modal }\end{array}$} & \multirow{2}{*}{ KINERIA AWAL RPIMD } & \multicolumn{5}{|c|}{ CAPAIAN KINERIA PROGRAM DAN KERANGKA PENDANAAN } & \multirow{2}{*}{\begin{tabular}{|c|} 
KINERIA AKHIR \\
PERIODE \\
\end{tabular}} \\
\hline & & 2014 & 2015 & 2016 & 2017 & 2018 & \\
\hline PENDANAAN (TOTAL) & & $\mathrm{Rp} 1.824 .450$ & $\mathrm{Rp} 1.885 .200$ & Rp1.724.150 & Rp1.824.050 & Rp1.942.950 & $\mathrm{Rp} 9.200 .800$ \\
\hline $\begin{array}{c}\text { Program kerjasama } \\
\text { investasi }\end{array}$ & $0.02 \%$ & 10-15\% & 10-15\% & $10-15 \%$ & $10-15 \%$ & $10-15 \%$ & $10-15 \%$ \\
\hline $\begin{array}{c}\text { Program penī ngkatan } \\
\text { PAD \& pendapatan } \\
\text { laīnya }\end{array}$ & $100 \%$ & $100 \%$ & $100 \%$ & $100 \%$ & $100 \%$ & $100 \%$ & $100 \%$ \\
\hline $\begin{array}{l}\text { Program penī ngkatan } \\
\text { kapasi tas sumber } \\
\text { daya Aparatur dalam } \\
\text { memahamī tugas } \\
\text { pokok dan fungsīi }\end{array}$ & $100 \%$ & $100 \%$ & $100 \%$ & $100 \%$ & $100 \%$ & $100 \%$ & $100 \%$ \\
\hline $\begin{array}{c}\text { Program realīsasī } \\
\text { indeks kepuasan } \\
\text { masyarakat terhadap } \\
\text { pelayanan KPPT }\end{array}$ & & 65\% & $67.5 \%$ & 71\% & 75\% & 83\% & 83\% \\
\hline
\end{tabular}

Sumber: data diolah

Di program penanaman modal pemerintah lebih fokus meningkatkan investasi sumber daya aparatur negara dalam lingkup daerah Kota Pangkalpinang dan melakukan realisasi investasinya dengan melihat indeks kepuasan masyarakat terhadap pelayanan KPPT dengan pencapaian kinerja pada tahun 2014 sebesar 65\% selanjutnya meningkat hingga 83\% diperiode 2018. Pemerintah juga melakukan program kerja sama investasi yang sudah berjalan dari awal 
program RPJMD 2013-2018 sebesar 0.02\% dengan persentase peningkatan dari tahun ketahun sebesar $10-15 \%$ bertujuan meningkatkan PAD dan pendapatan lainya. Sehingga Pemerintah melakukan pendanaan dengan total pengeluaransebesar Rp.9.200.800,-.Untuk kedepannya pemerintah dapat meningkatkan promosi investasi sehingga dapat meningkatkan PAD Kota Pangkalpinang.

\subsubsection{Pertanian}

Tabel 4.5 Program Pertanian

\begin{tabular}{|c|c|c|c|c|c|c|c|}
\hline \multirow[b]{2}{*}{ PROGRAM Petanian } & \multirow{2}{*}{ KINERAAWAL RPJMD } & \multicolumn{5}{|c|}{ CAPAIAN KINERLA PROGRAM DAN KERANGKA PENDANAMN } & \multirow{2}{*}{$\begin{array}{l}\text { KINERIAAKHIR } \\
\text { PERIODE }\end{array}$} \\
\hline & & 2014 & 2015 & 2016 & 2017 & 2018 & \\
\hline PENDANAAN (TOTAL) & & Rp6.938.493 & Rp5.284.204 & $\operatorname{Rp5} .787 .874$ & Rp4.746.871 & Rp6.893.308 & Rp29.650.750 \\
\hline $\begin{array}{c}\text { Program Peningkatan } \\
\text { petani pelaku } \\
\text { agribisnis yang } \\
\text { produktif }\end{array}$ & 55 org $69 \mathrm{KT}$ & $\begin{array}{l}30 \text { org, } 76 \mathrm{KT}, \\
20 \text { org, } 25 \text { org }\end{array}$ & $\begin{array}{c}55 \text { org } 79 \mathrm{KT}, \\
50 \mathrm{KT}, 25 \mathrm{org}, 1 \\
\text { dok }\end{array}$ & $\begin{array}{c}25 \text { org, } 80 \mathrm{KT}, 25 \\
\text { org, } 1 \text { dok }\end{array}$ & $\begin{array}{c}25 \text { org, } 80 \\
\mathrm{KT}, 50 \mathrm{KT}, 25 \\
\operatorname{org} 1 \text { dok }\end{array}$ & $\begin{array}{l}25 \text { org, } 80 \mathrm{KT}, \\
25 \text { org, } 1 \text { dok }\end{array}$ & $\begin{array}{c}130 \mathrm{org}, 80 \mathrm{KT}, 50 \\
\mathrm{KT}, 25 \mathrm{org}, 20 \text { org, } 1 \\
\text { dok }\end{array}$ \\
\hline $\begin{array}{c}\text { Program peningkatan } \\
\text { ketahanan pangan } \\
\text { pertanian/perkebuna } \\
\text { n (pendistrubusian } \\
\text { pukpuk bersubsid) }\end{array}$ & $\begin{array}{c}5 \text { Kex, } 100 \%, 282 \text { ton } \\
10 \text { orang }\end{array}$ & $\mid \begin{array}{c}5 \text { Ker, } 100 \% \\
282 \text { ton , } 12 \\
\text { org, } 100 \%\end{array}$ & $\begin{array}{c}2 \text { ha, } 20 \%, 282 \\
\text { ton, } 100 \%\end{array}$ & $\begin{array}{c}3 \text { ha, } 20 \%, 282 \\
\text { ton, } 100 \%\end{array}$ & $\begin{array}{c}4 \text { ha, } 20 \%, 282 \\
\text { ton, 100\% }\end{array}$ & $\begin{array}{c}4 \text { ha, } 20 \%, 282 \\
\text { ton, } 100 \%\end{array}$ & $\begin{array}{c}2 \mathrm{kec}, 4 \text { ha, } 100 \% \text {, } \\
282 \text { ton, } 12 \text { org } \\
100 \%\end{array}$ \\
\hline $\begin{array}{c}\text { Program peningkatan } \\
\text { sarana \& prasarana } \\
\text { RPH,RPU, \& pasar } \\
\text { daging } \\
\end{array}$ & 80\% RPH,20\% RPU & $\begin{array}{c}80 \% \mathrm{RPH}, 20 \% \\
\mathrm{RPU}, 1 \text { paket }\end{array}$ & $\begin{array}{c}100 \% \text { (RPH \& } \\
\text { RPU) }\end{array}$ & $\begin{array}{c}100 \%(\mathrm{RPH} \& \\
\text { RPU) }\end{array}$ & $\begin{array}{c}100 \%(\mathrm{RPH} \& \\
\mathrm{RPU})\end{array}$ & $\begin{array}{l}\text { 100\% Pasar } \\
\text { Daging }\end{array}$ & $100 \%$ \\
\hline $\begin{array}{c}\text { Program Peningkatan } \\
\text { Penerapan Tekonologi } \\
\text { Petermakan }\end{array}$ & $\begin{array}{c}12 \text { Ekor Sapi IB, } 1 \\
\text { PaketAat RPH }\end{array}$ & $\begin{array}{c}25 \text { Ekor Sapi } \\
\text { Hasil IB, } 1 \\
\text { Unitalat } \\
\text { biogas }\end{array}$ & \begin{tabular}{|c|}
25 Ekor Sapi \\
Hasil IB, 1 \\
paket alat RPH, \\
1 Paketalat \\
pakan unggas, \\
25 org petemak \\
\& Unggas
\end{tabular} & $\begin{array}{c}25 \text { Ekor Sapi } \\
\text { Hasil IB, } 1 \text { Paket } \\
\text { alat pakan } \\
\text { ruminansia, } 25 \\
\text { org peternak \& } \\
\text { petugas, } 1 \text { unit } \\
\text { alat biogas }\end{array}$ & $\begin{array}{c}25 \text { Ekor Sapi } \\
\text { hasil IB, 25 } \\
\text { org petemak \& } \\
\text { pelugas }\end{array}$ & $\begin{array}{c}25 \text { Ekor Sapi } \\
\text { hasil IB, } 25 \text { org } \\
\text { peternak \& } \\
\text { petugas, } 1 \text { Unit } \\
\text { alatbiogas }\end{array}$ & $\begin{array}{l}125 \text { Ekor Sapi hasil } \\
\text { IB, } 1 \text { paket alat RPH, } \\
1 \text { Paket alat pakan } \\
\text { unggas, } 1 \text { paket alat } \\
\text { pakat ruminansia, } \\
25 \text { peternak \& } \\
\text { petugas, } 3 \text { unitalat } \\
\text { unggas }\end{array}$ \\
\hline
\end{tabular}

Sumber: data diolah

Program yang dibuat di RPJMD ada beberapa program seperti peningkatan ketahanan pangan pertanian/perkebunan dan peternakan dengan pendistribusian pupuk bersubsidi dan memfasilitasi alat teknologi untuk penerapanya, serta meningkatkan sarana prasarana RPH, RPU \& Pasar Daging dibeberapa program yang dibuat dari RPJMD 2013 dapat diketahui keberhasilan rata-rata $100 \%$ total biaya diakhir kinerja tahun 2018 sebesar Rp. 29.650.750,-. Kedepannya Pemerintah diharapkan dapat menganggarkan dana yang lebih untuk meningkatkan kesejahteraan petani \& peternak sehingga berpengaruh juga terhadap pendapatan daerah. 


\subsubsection{Energi Dan Sumber Daya Mineral Tabel 4.4.6 Program Energi \& Sumber Daya Mineral}

\begin{tabular}{|c|c|c|c|c|c|c|c|}
\hline \multirow{2}{*}{$\begin{array}{l}\text { PROGRAM Enegi \& } \\
\text { sumber Daya mineral }\end{array}$} & \multirow{2}{*}{ KINERIA AWAL RPJMD } & \multicolumn{5}{|c|}{ CAPAIAN KINERIA PROGRAM DAN KERANGKA PENDANAAN } & \multirow{2}{*}{$\begin{array}{l}\text { KINERIA AKHIR } \\
\text { PERJODE }\end{array}$} \\
\hline & & 2014 & 2015 & 2016 & 2017 & 2018 & \\
\hline PENDANAAN (TOTAL) & & Rp368.728 & $\operatorname{Rp} 650.000$ & Rp715.000 & Rp786.500 & Rp865.150 & Rp3.385.378 \\
\hline $\begin{array}{l}\text { Program Pembinaan } \\
\text { Pengawasan Sumber } \\
\text { daya Mineral }\end{array}$ & $\begin{array}{c}57.14 \% \text { Hasil pada } 4 \\
\text { kec dari } 7 \text { Kec }\end{array}$ & $57.14 \%$ & $85.71 \%$ & $100 \%$ & $100 \%$ & $100 \%$ & $100 \%$ \\
\hline $\begin{array}{c}\text { Program penbinaan } \\
\text { dan pengentbangan } \\
\text { ketenagalistrikan } \\
\text { (Rasio keter sediaan } \\
\text { daya listrik) }\end{array}$ & $9620 \%$ & $9620 \%$ & $9620 \%$ & $9620 \%$ & $9620 \%$ & $9620 \%$ & $9620 \%$ \\
\hline
\end{tabular}

Sumber: data diolah

Pemerintah melakukan pembinaan dan pengawasan sumber daya mineral dihitung dari awal periode $57.14 \%$ diambil sampel yang akurat dari 7 kecamatan diambil 4 kecamatan, dan pengembangan ketenagalistrikan dengan indikator kerja rasio ketersediaan daya listrik diawal program sebesar $96.2 \%$ yang diambil data dari PT.PLN Cabang dapat diketahui total dana yang dikeluarkan pemerintah sebesar 3.385.378,-. Bisa dikatakan Pemerintah Kota Pangkalpinang berhasil dalam pembinaan pengawasan terhadap Energi dan Sumber Daya Mineral, sehingga dapat memenuhi energi listrik yang disalurkan kemasyarakat khususnya daerah Kota Pangkalpinang .

\subsubsection{Pariwisata}

\section{Tabel 4.7 Program Pariwisata}

\begin{tabular}{|c|c|c|c|c|c|c|c|}
\hline \multirow{2}{*}{$\begin{array}{c}\text { PROGRAM } \\
\text { PARIWISATA }\end{array}$} & \multirow{2}{*}{ KINERUAAWAL RPJMD } & \multicolumn{5}{|c|}{ CAPAIAN KINERIA PROGRAM DAN KERANGKA PENDANAAN } & \multirow{2}{*}{$\begin{array}{c}\text { KINERIA AKHIR } \\
\text { PERIODE } \\
\end{array}$} \\
\hline & & 2014 & 2015 & 2016 & 2017 & 2018 & \\
\hline PENDANAAN (TOTAL) & & Rp4.593.000 & Rp11.253.818 & Rp875.500 & Rp7.047.000 & Rp10.290.000 & Rp41.938.818 \\
\hline $\begin{array}{c}\text { Program } \\
\text { Pengentrangan } \\
\text { destinasi Pariwisata } \\
\text { (Kunjungan } \\
\text { wisatawan dim } 1 \text { thn) }\end{array}$ & 364008 orang & $\begin{array}{c}100.000 \\
\text { orang }\end{array}$ & 105.000 orang & 110000 orang & 115.000 orang & 120000 or ang & 550.000 orang \\
\hline $\begin{array}{c}\text { Program } \\
\text { pengembangan } \\
\text { kontribusi retribusi } \\
\text { sektor pariwisata } \\
\text { trohadap PAD }\end{array}$ & $17.20 \%$ & $20 \%$ & $20 \%$ & $20 \%$ & $20 \%$ & $20 \%$ & $100 \%$ \\
\hline
\end{tabular}

Sumber: data diolah

Didalam Program ini pemerintah mengembangkan destinasi pariwisata yang diukur keberhasilannya program melalui kunjungan wisata dalam 1 tahun, serta pengembangan kontribusiretribusi dengan tujuan meningkatkan persentase sektor terhadap PAD dan diawal program telah mencapai $17.20 \%$ dengan tingakt keberhasilanya pada akhir periode kinerja sebsear 100\% dengan total biaya yang diakhir tahun 2018 sebesar Rp. 41.938.818.

\subsubsection{Kelautan dan Perikanan}


Tabel 4.8 Program Kelautan dan Perikanan

\begin{tabular}{|c|c|c|c|c|c|c|c|}
\hline \multirow{2}{*}{$\begin{array}{l}\text { PROGRAM KEAUTAN } \\
\text { \& PERIKANAN }\end{array}$} & \multirow{2}{*}{ KINERIA AWAL RPJMD } & \multicolumn{5}{|c|}{ CAPAIAN KINERIA PROGRAM DAN KERANGKA PENDANAAN } & \multirow{2}{*}{$\begin{array}{l}\text { KINERUAAKHIR } \\
\text { PERIODE }\end{array}$} \\
\hline & & 2014 & 2015 & 2016 & 2017 & 2018 & \\
\hline PENDANAAN (TOTAL) & & Rp5.766.398 & Rp3.744.287 & Rp6.566.302 & Rp5.994.949 & Rp4.299.782 & Rp26.301.718 \\
\hline $\begin{array}{c}\text { Program } \\
\text { Pengernbangan } \\
\text { Produksi Perikanan } \\
\text { Tangkap }\end{array}$ & $24.439 \mathrm{Ton}$ & 20209 Ton & 20333 Ton & 20.432 Ton & 20505 Ton & 20.641 Ton & 20.641 Ton \\
\hline $\begin{array}{c}\text { Program } \\
\text { Pengernbangan } \\
\text { Produksi Perikanan } \\
\text { Budidaya }\end{array}$ & 3.454 Ton & $2995 \mathrm{Ton}$ & $3500 \mathrm{Ton}$ & $3045 \mathrm{Ton}$ & 3091 Ton & 3.137 Ton & 3.137 Ton \\
\hline $\begin{array}{c}\text { Program Penyuluhan } \\
\text { Binaan KUB }\end{array}$ & $24 \%$ & $100 \%$ & $100 \%$ & $100 \%$ & $100 \%$ & $100 \%$ & $100 \%$ \\
\hline $\begin{array}{c}\text { Program } \\
\text { Pemberdayaan } \\
\text { Masyarakat dalam } \\
\text { Pengawasan dan } \\
\text { pengendalian Sumber } \\
\text { Daya Kelautan (luas } \\
\text { kawasan konservasi } \\
\text { \& rehabilitas) }\end{array}$ & $50 \% / 2.1$ & $100 \% / 0.6$ & $100 \% / 02$ & $100 \% / 02$ & $100 \% / 02$ & $100 \% / 02$ & $100 \% / 02$ \\
\hline
\end{tabular}

Sumber: data diolah

Pemerintah melakukan pengembangan produksi perikanan tangkap maupun budidaya, dengan produksi perikanan tangkap sebesar 20.641 Ton diakhir periode sedangkan untuk produksi perikanan budidaya sebesar 3.137 Ton. Lebih baiknya Pemerintah dapat lebih meningkatkan program pengembangan produksi perikanan budidaya dibanding dengan tangkap, karena lebih jelas dapat menjaga ekosistem kelautan dilihat dari indikator lebih banyak produksi ikan tangkap sedangkan produksi ikan budidaya hanya sedikit. Pemerintah juga melakukan pemberdayaan masyarakat dengan pengendalian dan pengawasan kawasan konservasi \& rehabilitas. Untuk beberapa program ini pengeluaran pemerintah sebesar Rp26.301.718.

\subsubsection{Perdagangan}

\section{Tabel 4.9 Program Perdagangan}

\begin{tabular}{|c|c|c|c|c|c|c|c|}
\hline \multirow{2}{*}{$\begin{array}{c}\text { PROGGAM } \\
\text { PERDAGANGAN }\end{array}$} & \multirow{2}{*}{ KINERUA AWAL RPJMD } & \multicolumn{5}{|c|}{ CAPAIAN KINERIA PROGRAM DAN KBRANGKA PENDANAAN } & \multirow{2}{*}{$\begin{array}{l}\text { KINERLAAKHIR } \\
\text { PERIODE }\end{array}$} \\
\hline & & 2014 & 2015 & 2016 & 2017 & 2018 & \\
\hline PENDANAAN (TOTAL) & & Rp6.565.388 & Rp19.559.776 & Rp25.251.993 & Rp19.878.741 & Rp23.512.115 & Rp94.768.012 \\
\hline $\begin{array}{c}\text { Program } \\
\text { Perlindungan } \\
\text { Konsumen dan } \\
\text { Pengamanan } \\
\text { Perdagangan }\end{array}$ & $25 \%$ & $40 \%$ & $40 \%$ & $45 \%$ & $55 \%$ & 659 & $65 \%$ \\
\hline $\begin{array}{c}\text { Program Peningkatan } \\
\text { dan Pengembangan } \\
\text { Bspor }\end{array}$ & 0\%6 & 1096 & $15 \%$ & $15 \%$ & 2006 & 2596 & 259 \\
\hline $\begin{array}{l}\text { Program Perinegtatan } \\
\text { Efisiensi Perdagengean } \\
\text { dalamnegeri }\end{array}$ & $35 \%$ & $40 \%$ & 416 & 426 & 4396 & 4436 & $45 \%$ \\
\hline $\begin{array}{l}\text { Program Pembinaan } \\
\text { pertagang katati lima \& } \\
\text { Asongan }\end{array}$ & 1436 & 259 & $40 \%$ & 5006 & $55 \%$ & 6096 & 6096 \\
\hline
\end{tabular}

Sumber: data diolah

Pemerintah wajib melakukan perlindungan konsumen dan pengamanan perdagangan dengan 
menjamin kualitas barang dan jasa yang beredar pada saat ini pemerintah mampu mengatasi program ini yang dilihat dari persentase dari awal hingga akhir kinerja meningkat hingga 65\% tetapi masih perlu di tingkatkan agar Konsumen dapat merasakan terlindungi serta perdagangan khususnya Kota Pangkalpinang lebih kondusif. Peningkatan dan pengembangan ekspor juga perlu jadi perhatian dari Pemerintah Kota Pangkalpinang karena masih dikatakan rendah untuk persentasenya hanya $45 \%$ di akhir kinerja hanya meningkat $0.1 \%$ dari tahun 2014, maka dari itu pemerintah perlu meningkatkan ekspor dari beberapa komoditi sehingga nilai ekspor dapat meningkat melalui variasi produk (pendalaman struktur) dan diversifikasi pasar (Negara/daerah tujuan).

Pedagang kaki lima dan asongan juga perlu mendapatkan pembinaan sehingga dapat memiliki daya saing untuk pasar dalam negeri dan berpotensi menembus pasar luar negeri. Di beberapa program perdagangan pemerintah telah mengeluarkan pendanaan dari awal kinerja RPJMD 2013-2018 sebesar Rp.94.768.012.

\subsubsection{Industri}

\section{Tabel 4.10 Program Industri}

\begin{tabular}{|c|c|c|c|c|c|c|c|}
\hline \multirow{2}{*}{ PROGRAM INDUSTRI } & \multirow{2}{*}{ KINERIA AWAL RPJMD } & \multicolumn{5}{|c|}{ CAPAAN KINERUA PROGRAM DAN KERANGKA PENDANAAN } & \multirow{2}{*}{$\begin{array}{l}\text { KINERIAAKHIR } \\
\text { PERIODE }\end{array}$} \\
\hline & & 2014 & 2015 & 2016 & 2017 & 2018 & \\
\hline PENDANAAN (TOTAL) & & Rp2.027.261 & Rp4.719.687 & Rp6.581.390 & Rp7.370.488 & Rp29.502.536 & $\operatorname{Rp} 50.201 .362$ \\
\hline $\begin{array}{c}\text { Program Peringkatan } \\
\text { PAD dan pendapatan } \\
\text { lainnya }\end{array}$ & $25 \%$ & $100 \%$ & $100 \%$ & $100 \%$ & $100 \%$ & $100 \%$ & $100 \%$ \\
\hline $\begin{array}{c}\text { Pengernbangan } \\
\text { Industri Keail \& } \\
\text { Menengah }\end{array}$ & 8 Unit & 4 Unit & 10 Unit & 16 Unit & 16 Uhit & 16 Unit & 16 Unit \\
\hline \begin{tabular}{|c|} 
Program \\
Pengernbangan Sentra \\
sentra Industri \\
Potensial \\
\end{tabular} & $30 \%$ & 35\% & $40 \%$ & 45\% & $50 \%$ & $60 \%$ & $65 \%$ \\
\hline $\begin{array}{c}\text { Program } \\
\text { Pengentangan } \\
\text { Kompetensi Inti } \\
\text { Industri }\end{array}$ & $5 \%$ & $7 \%$ & $10 \%$ & $12 \%$ & $16 \%$ & $20 \%$ & $20 \%$ \\
\hline $\begin{array}{c}\text { Program } \\
\text { Pernbangunan \& } \\
\text { Permbangunan } \\
\text { Kawasan Industri }\end{array}$ & O\% & 0\% & $5 \%$ & $10 \%$ & $15 \%$ & $20 \%$ & $20 \%$ \\
\hline
\end{tabular}

Sumber: data diolah

Program peningkatan PAD dan Pendapatan lainnya dengan terbukti meningkatnya persentase dan pendapatan daerah di tahun 2013 100\% dari awal kinerja RPJMD hanya sebesar 25\%, untuk perkembangan industri kecil\& menengah dihitung dari jumlah berkembangnya hingga 16 unit, di bidang industri pemerintah juga meningkatkan dan mengembangkan sentra-sentra industri potensial dengan persentase hanya $65 \%$ perlu ditingkatkan lagi agar industri yang berpotensi semakin berkembang pesat agar dapat menaikkan PAD Kota Pangkalpinang, serta perlu ditingkatkan lagi pembangunan-pembangunan kawasan industri karena masih rendah dilihat dari indikator kinerja dalam jangka periode rancangan pembangunan yang hanya mencapai 20\% ditahun 2018. Dari beberapa program yang dijalankan Pemerintah Kota Pangkalpinang telah mengeluarkan dana untuk pembangunan disektor industri dengan total pengeluaran pemerintah sebesar Rp.50.201.362. 


\section{KESIMPULAN}

Berdasarkan analisis kami mengenai kebijakan pembangunan ekonomi di Kota Pangkalpinang menujukkan bahwa sebenarnya Kota Pangkalpinang ini punya potensi yang sangat besar terhadap peningkatan pembangunan daerah di beberapa sektor salah satunya selain sector industry dan sector perdagangan besar dan eceran namun sektor pariwista yang termasuk kedalam kelompok dengan tingkat pertumbuhan yang cukup rendah dan sumbangan terhadap nilai PDRB daerahnya masih rendah. Sektor lain yang mempunyai prospek yang cukup bagus dalam prioritas pembangunan ekonomi daerah adalah adalah sektor UMKM yang dapat ditunjukkan dari penyerapan tenaga kerja yang cukup lumayan tinggi di tahun 2018.

\section{REFERENSI}

\section{Buku}

Sjafrizal. 2009. Ekonomi Regional: Teori dan Aplikasi. Jakarta: Niaga Swadaya

Tarigan, Robinson. 2014. Ekonomi Regional Teori dan Aplikasi Edisi Revisi. Jakarta: Bumi Aksara.

\section{Buku Elektronik}

P. Todaro, Michael. Stephen C. Smith. 2012. Economic Development $11^{\text {th }}$ Edition. New York :Pearson Press.

For an organizational or government report or document with no author(s): BPS Pangkalpinang, 2013. Kota Pangkalpinang dalam Angka Tahun 2013. Pangkalpinang: Publikasi BPS Pangkalpinang

BAPPEDA Pangkalpinang. 2013. Indikasi Rencana Program Prioritas yang disertai pendanaan. Pangkalpinang: Publikasi BAPPEDA Pangkalpinang

BAPPEDA Pangkalpinang. 2013. Rancangan Pembangunan Jangka Menengah Daerah 2013,.Pangkalpinang: BAPPEDA Pangkalpinang

BAPPEDA Pangkalpinang . 2018. Rancangan Kinerja Pembangunan Daerah Pangkalpinang 2018.Pangkalpinang: BAPPEDA Pangkalpinang 